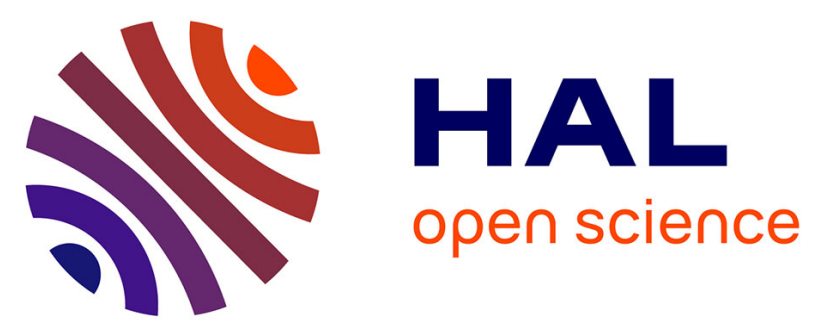

\title{
A comparison of soil microbial community structure, protozoa and nematodes in field plots of conventional and genetically modified maize expressing the Bacillus thuringiensis CryIAb toxin
}

B.S. S Griffiths, S. Caul, J. Thompson, A.N.E. N E Birch, C. Scrimgeour, M.N. N Andersen, Jérôme Cortet, A. Messéan, C. Sausse, B. Lacroix, et al.

\section{To cite this version:}

B.S. S Griffiths, S. Caul, J. Thompson, A.N.E. N E Birch, C. Scrimgeour, et al.. A comparison of soil microbial community structure, protozoa and nematodes in field plots of conventional and genetically modified maize expressing the Bacillus thuringiensis CryIAb toxin. Plant and Soil, 2005, 275 (1-2), pp.135-146. 10.1007/s11104-005-1093-2 . hal-03218706

\author{
HAL Id: hal-03218706 \\ https://hal.science/hal-03218706
}

Submitted on 5 May 2021

HAL is a multi-disciplinary open access archive for the deposit and dissemination of scientific research documents, whether they are published or not. The documents may come from teaching and research institutions in France or abroad, or from public or private research centers.
L'archive ouverte pluridisciplinaire HAL, est destinée au dépôt et à la diffusion de documents scientifiques de niveau recherche, publiés ou non, émanant des établissements d'enseignement et de recherche français ou étrangers, des laboratoires publics ou privés. 


\title{
A comparison of soil microbial community structure, protozoa and nematodes in field plots of conventional and genetically modified maize expressing the Bacillus thuringiensis CryIAb toxin
}

\author{
B.S. Griffiths ${ }^{1,7}$, S. Caul ${ }^{1}$, J. Thompson ${ }^{1}$, A.N.E. Birch ${ }^{1}$, C. Scrimgeour ${ }^{1}$, M.N. Andersen ${ }^{2}$,

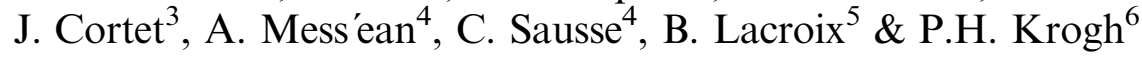

Key words: Bacillus thuringiensis toxin, genetically modified plants, maize, microbial community structure, nematodes, protozoa

\begin{abstract}
Field trials were established at three European sites (Denmark, Eastern France, South-West France) of genetically modified maize (Zea mays L.) expressing the CryIAb Bacillus thuringiensis toxin (Bt), the nearisogenic non-Bt cultivar, another conventional maize cultivar and grass. Soil from Denmark was sampled at sowing (May) and harvest (October) over two years $(2002,2003)$; from E France at harvest 2002, sowing and harvest 2003; and from SW France at sowing and harvest 2003. Samples were analysed for microbial community structure (2003 samples only) by community-level physiological-profiling (CLPP) and phospholipid fatty acid analysis (PLFA), and protozoa and nematodes in all samples. Individual differences within a site resulted from: greater nematode numbers under grass than maize on three occasions; different nematode populations under the conventional maize cultivars once; and two occasions when there was a reduced protozoan population under Bt maize compared to non-Bt maize. Microbial community structure within the sites only varied with grass compared to maize, with one occurrence of CLPP varying between maize cultivars (Bt versus a conventional cultivar). An overall comparison of Bt versus non-Bt maize across all three sites only revealed differences for nematodes, with a smaller population under the Bt maize. Nematode community structure was different at each site and the Bt effect was not confined to specific nematode taxa. The effect of the Bt maize was small and within the normal variation expected in these agricultural systems.
\end{abstract}

\section{Introduction}

The global commercial area of genetically modified (GM) plants reached $67.7 \mathrm{M}$ ha in 2003 and

\footnotetext{
*E-mail: bgriff@scri.sari.ac.uk
}

that of GM maize expressing the Bacillus thuringiensis toxin (Bt) was 9.1 M ha (James, 2003). Even so, the environmental release of GM plants is still controversial due to the potential negative effects on human health and the environment, including effects on non-target soil organisms (Wolfenbarger and Phifer, 2000). The 
potential for effects of Bt crops on non-target soil organisms is considerable as the protein is expressed constitutively in all parts of the plant (Wilkinson et al., 1997), so both plant residues remaining after harvest and root exudates released during plant growth could contain $\mathrm{Bt}$ toxin and be incorporated into the soil. Sims and Ream (1997) estimated that a potential maximum of $1.6 \mu \mathrm{g}$ CryIIA protein $\mathrm{g}^{-1}$ soil would result from the residues of a crop of $\mathrm{Bt}$ cotton, while Saxena et al. (2002) observed that CryIAb toxin was released in root exudates from $12 \mathrm{Bt}$ maize hybrids, accumulated in soil and remained insecticidal for up to 180 days.

Despite the large area of Bt maize and other crops, and the potential for effects on non-target soil organisms, the number of studies is still relatively small (see for example reviews by Bruinsma et al., 2003; Groot and Dicke, 2002). There were, for example, increased numbers of bacteria and fungi under $\mathrm{Bt}$ cotton (toxin from Bacillus thuringiensis ssp. kurstaki; Donegan et al., 1995) but minimal differences under $\mathrm{Bt}$ potato (toxin from Bacillus thuringiensis ssp. tenebrionis; Donegan et al., 1996). Differences were seen in the decomposition of $\mathrm{Bt}$ maize (CryIAb; Escher et al., 2000) but no effects of Bt maize on populations of earthworms, nematodes, protozoa or microbes (CryIAb; Saxena and Stotsky, 2001) or any direct effects of the consumption of Bt crops or exposure to $\mathrm{Bt}$ toxin on a soil mite and collembolan (CryIAb, CryIAc, CryIIA, CryIIIA; Sims and Martin, 1997; Yu et al., 1997). There have been contrasting results of effects on soil nematodes, with no effect on nematode community structure under Bt eggplant (CryIIIBb; Manachini et al., 2003) but a distinct shift in community structure under Bt oilseed rape (CryIAc; Manachini et al., 2004). In series of experiments with $\mathrm{Bt}$ rice, the incorporation of transgenic rice straw into flooded paddy soil altered some important biological properties in one study (CryIAb; Wu et al., 2004) but was shown to be non-toxic to a variety of culturable microorganisms in another (CryIAb; Wei-Xiang et al., 2004).

It was to address this lack of study on the effects of $\mathrm{Bt}$ expressing crops on soil populations and processes that the EU-funded ECOGEN project (www.ecogen.dk) was initiated. This interdisciplinary study has followed the advice of previous expert panels in adopting a tiered approach (i.e. laboratory, glasshouse and field experiments, Angle, 1994) with an emphasis on soil communities and ecosystem functioning (Jepson et al., 1994; Trevors et al., 1994). Within the ECOGEN project there are three field sites in different European climatic zones where $\mathrm{Bt}$ maize and a non-Bt near-isogenic control are grown. While it is clearly essential to compare the $\mathrm{Bt}$ crop with its genetically closest available variety to determine whether there are any effects attributable to the Bt variety, it is also essential to be able to put the magnitude of these changes into context. To be able to compare any differences that might be measured between these varieties we also took samples from another, conventional, maize variety. Although a comparison of only three maize varieties is insufficient to cover the range of potential varietal effects, it would at least allow some assessment of the Bt variety against non-GM varieties. Finally, we also took samples from the surrounding plots of grass, which would allow comparison of the differences due to maize variety, including $\mathrm{Bt}$, with the magnitude of the changes due to growing another common crop. This approach has been used previously (Schmalenberger and Tebbe, 2003) and permits any observed changes due to the GM plant to be related to the magnitude of changes between different crops.

This paper reports on the field determinations of microbial community structure (both phospholipid fatty acid, PLFA, and community level physiological, CLPP, profiles were characterized in the second year), protozoa and nematodes from the first two years of the project.

\section{Materials and methods}

\section{Field sites and soil}

The three locations selected to achieve differing climatic and soil conditions were in Foulum, Varois and Narbons. Foulum is the most northerly field site at $56^{\circ} 30^{\prime} \mathrm{N}, 9^{\circ} 35^{\prime} \mathrm{E}$ at the Danish Institute of Agricultural Sciences (DIAS), Denmark. The soil is a loamy sand $(62.2 \%$ sand, $23.2 \%$ silt, $8.3 \%$ clay) containing $6.4 \%$ organic matter. The other two sites were in different regions of 
France. Varois is the intermediate location in Varois et Chaignot (Cote d'or), Bourgogne, $47^{\circ} 34^{\prime} \mathrm{N}, 5^{\circ} 13^{\prime} \mathrm{E}$, with a clay-silt soil, (20\% sand, $41 \%$ silt, $30 \%$ clay) containing $1.9 \%$ organic matter. The second French site Narbons is the most southerly, located in Baziege, Midi-Pyrenees, $43^{\circ} 26^{\prime} \mathrm{N}, 1^{\circ} 27^{\prime} \mathrm{E}$, with a clay soil (39\% sand, $31 \%$ silt, $25 \%$ clay) containing $1.7 \%$ organic matter.

\section{Experimental design}

At Foulum there were three treatments of different maize (Zea mays L.) cultivars in a four-block design with three randomised plots $(45 \mathrm{~m}$ $\times 30 \mathrm{~m}$ ) in each block. Each plot was separated by $15 \mathrm{~m}$ of grassland and the outer perimeter of the plots surrounded with $20 \mathrm{~m}$ grassland. The cultivars used were: MEB307Bt (a Mon 810 Bt-variety expressing the CrylAb protein, from Monsanto); Monumental (a registered conventional variety near-isogenic to MEB307Bt but without the Bt-trait) and DK242 (a registered conventional variety). The field was ploughed and prepared for sowing by application of $30 \mathrm{t} \mathrm{ha}^{-1}$ of cattle slurry in autumn 2001. At seeding, May 2002, $150 \mathrm{~kg} \mathrm{ha}^{-1}$ NPK fertiliser (17-9-0) was applied which was supplemented in June with $200 \mathrm{~kg} \mathrm{ha}^{-1}$ calcium-ammoniumnitrate fertiliser containing ca. $27 \%$ N. Other field operations, herbicide application for example, were also the same for all plots. The maize plants were harvested in October. This design was repeated in the same plots in 2002 and 2003.

At Varois there were two treatments of different maize cultivars in a four-block design with two randomised plots $(12 \mathrm{~m} \times 19 \mathrm{~m})$ in each block, not separated by grass but with grass surrounding the outer perimeter of the plots. The maize cultivars were MEB307Bt and Monumental as at Foulum. The field was ploughed, seeded in May and after seeding $130 \mathrm{~kg} \mathrm{ha}^{-1}$ ammonium nitrate fertiliser was applied. Pre- and post-emergence herbicides and insecticides were applied as standard practice to all plots. The maize plants were harvested in October. This design was repeated in the same plots in 2002 and 2003.

The site at Narbons was only used in 2003. There were three treatments of different maize cultivars in a four-block design with three randomised plots $(12 \mathrm{~m} \times 20 \mathrm{~m})$ in each block. Each plot was separated by $7 \mathrm{~m}$ of grass sown at the same time as the maize (new grass) and the outer perimeter or the plots surrounded with $5 \mathrm{~m}$ of mature grass (old grass). The maize cultivars, suited for the regional climate, were: MEB552Bt (a Mon 810 Bt-variety expressing the Cry1Ab protein, from Monsanto); DK532 (a registered conventional variety near-isogenic to MEB552Bt but without the Bt-trait); and DK312 (a registered conventional variety). The field was ploughed, seeded in May and after seeding $180 \mathrm{~kg} \mathrm{ha}^{-1}$ ammonium nitrate fertiliser was applied. Pre- and post-emergence herbicides were applied as standard practice to all plots. The plots were irrigated regularly throughout the growing season and maize plants were harvested in October.

For contractual reasons it was not possible to sample all sites on all occasions. Samples were taken at sowing and harvest in both years at Foulum (i.e. May 2002, October 2002, May 2003, October 2003), on three occasions at Varois (i.e. October 2002, May 2003, October 2003) and only in 2003 at Narbons (i.e. May 2003, October 2003).

\section{Soil sampling}

Two separate composite soil samples were collected from the top $15 \mathrm{~cm}$ of each plot by taking 20 cores with a gouge auger (Eijkelkamp, Giesbeek, The Netherlands) in a stratified random design. The soil cores from the maize plots were collected within the rows, between the plants, while those from the grass plots were collected at random. The soil was sieved through a 4-mm diameter mesh and stored in sterile $50-\mathrm{mL}$ plastic tubes at $4{ }^{\circ} \mathrm{C}$ for transport back to the laboratory. Gravimetric water content was determined at $105{ }^{\circ} \mathrm{C}$. Nematodes were extracted from ca. $20 \mathrm{~g}$ fresh soil from each sample using a Whitehead and Hemming tray technique. Nematodes collected after $48 \mathrm{~h}$ were heat-killed for $2 \mathrm{~min}$ at $60{ }^{\circ} \mathrm{C}$ and preserved in $4 \%$ formaldehyde. Total nematode numbers were counted under low-power microscopy, then further processed through glycerol and mounted on a glass slide for identification at higher magnification. Total numbers of protozoa (i.e. active and encysted forms) were recorded in one sample from each plot by a most probable number technique 
(Darbyshire et al., 1974) in which $5 \mathrm{~g}$ soil were dispersed in $50 \mathrm{~mL}$ Neffs Modified Amoeba Saline (NMAS; Page, 1976) on a roller bed for $20 \mathrm{~min}$. Four $100-\mu \mathrm{L}$ aliquots were added to flatbottomed microtitre plates and diluted 3-fold in 50- $\mu \mathrm{L}$ sterile nutrient broth (Oxoid) in NMAS at 1:9 v:v. The microtitre plates were incubated at $15^{\circ} \mathrm{C}$ and the presence of flagellates, ciliates and amoebae recorded after 7,14 and 21 days. Numbers were calculated according to Hurley and Roscoe (1983) and biomass calculated using approximate weights (Griffiths and Caul, 1993). The soil:saline suspension was also used to determine the community-level physiological profile (CLPP, year 2 only). The suspension was further diluted in sterile NMAS to give an absorbance of 0.4 at $595 \mathrm{~nm}$ and $150 \mu \mathrm{L}$ inoculated into each well of a Biolog GN2 plate (Oxoid). The absorbance of each well at $595 \mathrm{~nm}$ was read initially and after incubation for 3, 4 and 5 days at $15^{\circ} \mathrm{C}$. Sub-samples of ca. $2 \mathrm{~g}$ were frozen at $-80{ }^{\circ} \mathrm{C}$ for later phospholipid fatty acid (PLFA) analysis. Total lipids were extracted from the frozen aliquots of soil with an extractant of citrate buffer, methanol and chloroform (Nielson and Petersen, 2000), PLFAs then separated by solid phase extraction, converted to methyl esters by mild alkaline transesterification and analysed by gas chromatography using a low polarity column (Frostegård et al., 1991).

\section{Bt maize CrylAb protein quantification}

To verify that the genetically modified plants were expressing the $\mathrm{Bt}$ toxin, $\mathrm{Bt}$ and non-Bt maize plants (a mixture of stems, leaves and ears from the Foulum site at harvest), were freeze dried and milled (Retsch mill, 0.2-mm sieve). Plant material from the French sites was destroyed for contractual reasons before any analyses could be carried out. The protein in plant material was determined using enzymelinked immunosorbent assay (ELISA) kits (PathoScreen kit for Bt-Cry1Ab/1Ac protein, Agdia Inc. USA) to quantify the Cry1Ab protein. For extraction, 1-mL of extraction buffer (MEB) was pipetted into $100 \mathrm{mg}$ powdered plant material in 2-mL Eppendorf tubes. The sample was then vortexed and clarified by centrifuging. A $100-\mu \mathrm{L}$ aliquot of the supernatant was dispensed in ELISA wells for measurement along with a dilution series of lyophilised positive controls and a negative control supplied with the kit. The test procedure described by the manufacturers was followed and optical densities of the wells were measured on a plate reader at $424 \mathrm{~nm}$.

\section{Statistical analysis}

Data were analysed using standard analysis of variance (ANOVA) procedures with the Rothamsted GENSTAT programme (Payne et al., 1993) and presented as means with an associated least significant difference (1sd, at the 5\% level) and degrees of freedom (d.f). The time-course profiles of the CLPP data were analysed from the area under the colour development profile (Hackett and Griffiths, 1997). This was calculated both from the raw (i.e. unadjusted) data and on data divided by the average well colour development (awcd). This acts to prevent the resulting analysis being biased by the rate of colour development rather than the pattern of colour development. The results of the CLPP time-course and the PLFA profile were analysed by principal component (PC) analysis and the resulting PC scores analysed by ANOVA.

\section{Results}

Soil water, nematodes and protozoa

The soil water content and population sizes of nematodes and protozoa at all three sites at each sampling occasion are detailed in Table 1. Significant differences between treatments at single sampling occasions are indicated. Further analysis revealed significant differences between sampling occasions and between sites. Differences will be discussed first on a site-by-site basis and secondly as a comparison of non-Bt versus $\mathrm{Bt}$ maize across all three sites. In the following descriptions, we present the least significant difference $(P<0.05)$ and the relevant degrees of freedom (d.f.) resulting from the ANOVA. Where there were significant interactions between the factors in the ANOVA (i.e. site (Foulum, Narbons or Varois), crop (maize cultivar or grass), month (May or October), year $(2002,2003)$ ) this is represented as an asterisk (*) between the appropriate factors. 


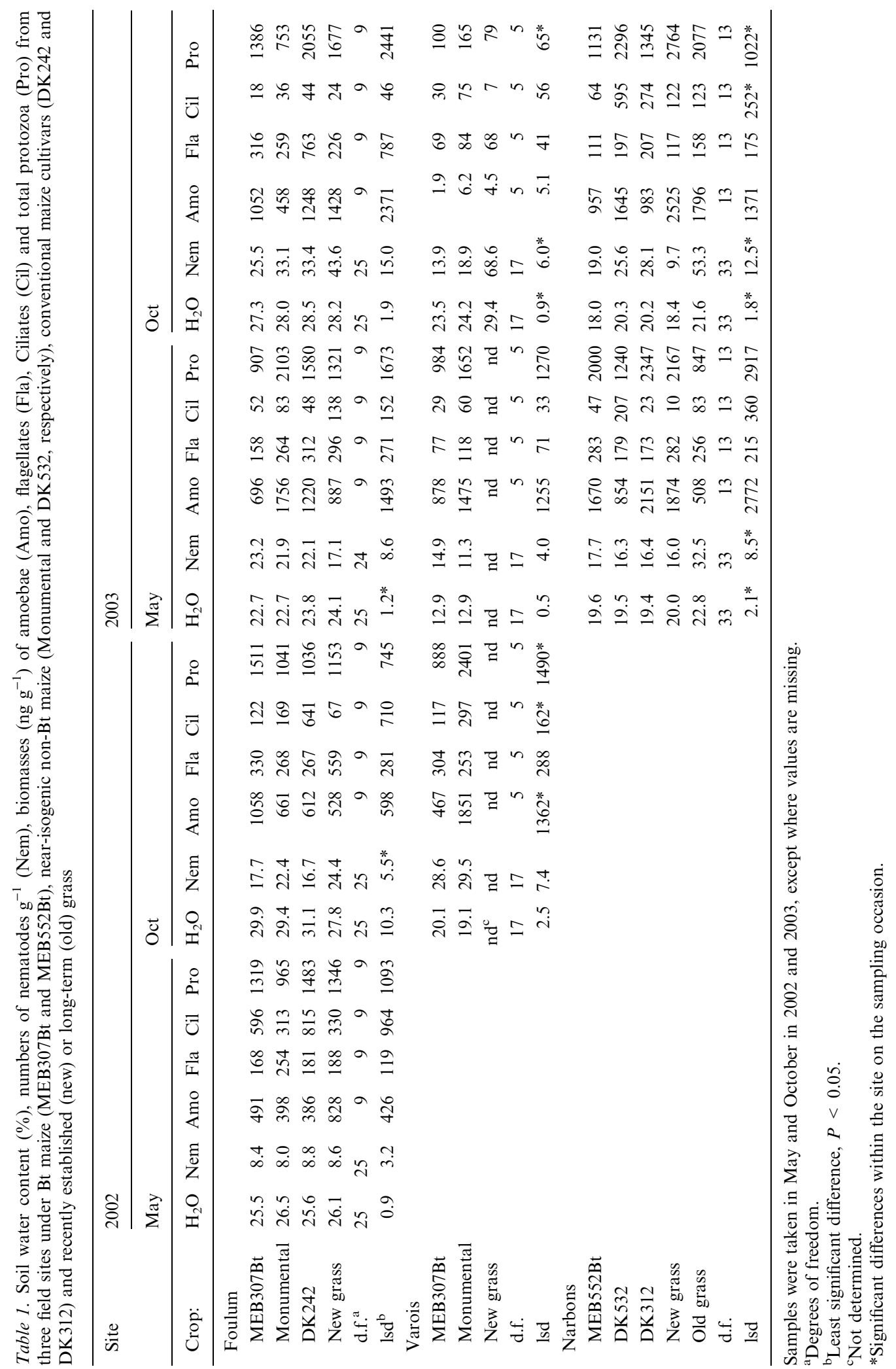


Table 2. Soil water content (\%) and ciliate biomass $\left(\mathrm{ng} \mathrm{g}^{-1}\right)$ at Foulum averaged over crop type

\begin{tabular}{lllll}
\hline & May & Oct & lsd $^{\mathrm{a}}$ & d.f. $^{\mathrm{a}}$ \\
\hline 2002 & & & & \\
$\% \mathrm{H}_{2} \mathrm{O}$ & 25.9 & 29.5 & 1.8 & 109 \\
$\mathrm{C}$ Ciliates & 1013 & 199 & 410 & 45 \\
2003 & & & & \\
$\% \mathrm{H}_{2} \mathrm{O}$ & 23.3 & 28.0 & & \\
Ciliates & 80 & 30 & & \\
\hline
\end{tabular}

asee Table 1.

At Foulum there were differences in soil water content between months and years, but no specific crop effects, so that soil in May was drier than in October and 2003 was drier than 2002 (Table 2). Nematodes showed month and year effects, there were more in 2003 $\left(\right.$ mean $\left.=27.5 \mathrm{~g}^{-1}\right)$ than in $2002\left(\right.$ mean $=14.2 \mathrm{~g}^{-1}$, lsd 3.3, 64 d.f.), and crop*month interactions in that nematode populations increased between May and October under all crops apart from the Bt variety MEB307Bt (Table 3). Amoebae (grand mean $=883 \mathrm{ng} \mathrm{g}^{-1}$ ) and flagellates (grand mean $=310 \mathrm{ng} \mathrm{g}^{-1}$ ) did not vary significantly over time, while ciliates showed month and year effects and month*year interactions resulting from a large population size in May 2002 (Table 2). Total protozoan biomass, however, did not vary significantly over time $\left(\right.$ grand mean $=1524 \mathrm{ng} \mathrm{g}^{-1}$ ).

At Varois, soil water content showed a month and year effect, with soil being wetter in Oct $2003(23.8 \%)$ than Oct $2002(19.6 \%)$ and May $2003(12.9 \%$, lsd 1.5, 39 d.f). Nematodes varied from month to month, with more in Oct 2002 $\left(19.6 \mathrm{~g}^{-1}\right)$ than either Oct $2003\left(16.4 \mathrm{~g}^{-1}\right)$ or May $2003\left(13.1 \mathrm{~g}^{-1}\right.$, 1sd 6.0, 39 d.f). Amoebae, ciliates and total protozoan biomass varied with crop

Table 3. Nematodes (no. $\mathrm{g}^{-1}$ ) from Foulum averaged over year under Bt maize (MEB307Bt), near-isogenic non-Bt maize (Monumental), conventional maize (DK242) and recently established (new) grass

\begin{tabular}{lllll}
\hline Crop & May & Oct & lsd $^{\mathrm{a}}$ & d.f $^{\mathrm{a}}$ \\
\hline MEB307Bt & 15.9 & 21.6 & 6.5 & 16 \\
Monumental & 14.7 & 27.7 & & \\
DL242 & 15.4 & 25.0 & & \\
New grass & 12.6 & 27.7 & & \\
\hline
\end{tabular}

asee Table 1. and month, with a small biomass in Oct 2003 and a greater biomass under non- $\mathrm{Bt}$ than $\mathrm{Bt}$ maize in Oct 2002 (Table 4). Flagellates only had a month effect, with more in Oct 2002 $\left(279 \mathrm{ng} \mathrm{g}^{-1}\right)$ than either Oct $2003\left(76 \mathrm{ng} \mathrm{g}^{-1}\right)$ or May 2003 (97 $\mathrm{ng} \mathrm{g}^{-1}$, 1sd 157, 39 d.f).

At Narbons, soil water varied with crop; soil under old grass (mean over time $=22.2 \%$ ) was wetter than all others $(19.6 \%$, 1sd $1.3,80$ d.f). Nematode populations had a crop*month interaction, as shown in Table 5. Amoebae (grand mean $=1480 \mathrm{ng} \mathrm{g}^{-1}$ ), flagellates (grand mean = $161 \mathrm{ng} \mathrm{g}^{-1}$ ), ciliates (grand mean $=1303 \mathrm{ng} \mathrm{g}^{-1}$ ) and total protozoan biomass (grand mean $=2944 \mathrm{ng}$ $\mathrm{g}^{-1}$ ) did not vary significantly over time.

In a three site comparison of Bt versus non$\mathrm{Bt}$, soil water content had significant month, site and crop effects, and site*month and crop*month interactions. Overall, the soil under nonBt maize was wetter than that under Bt maize in Oct 2003 (Table 6). Nematodes also varied with crop and month, showing a significant increase under non-Bt but not Bt maize between May and October 2003 (Table 6).

Comparison of the nematode community structure between the non-Bt and Bt plots in October 2003 showed quite clearly that the communities differed between the three sites but not with the crop type. Thus, at Narbons the community was dominated by Helicotylenchus, at Foulum there was a more even distribution of taxa between Aphelenchidae, Cephalobidae, Pratylenchus, Rhabditidae and Tylenchidae, while at Varois there was greater domination by Aphelenchidae and Cephalobidae, with a smaller but significant presence of Dorylaimidae, Helicotylenchus, Pratylenchus and Tylenchidae. The community composition at each site was similar between the $\mathrm{Bt}$ and nonBt cultivars (Figure 3).

Amoebae (grand mean $=1002 \mathrm{ng} \mathrm{g}^{-1}$ ) and total protozoan biomass (grand mean $=1762$ $\mathrm{ng}^{-1}$ ) did not vary significantly. Ciliates showed a month*site*crop interaction, but only due to a biomass under non-Bt maize from Narbons in Oct $2003\left(1064 \mathrm{ng} \mathrm{g}^{-1}\right)$ that was larger than all other treatments (Table 1). Flagellates varied significantly between sites, there were more at Foulum $\left(249 \mathrm{ng} \mathrm{g}^{-1}\right)$ and Narbons $\left(209 \mathrm{ng} \mathrm{g}^{-1}\right)$ than Varois (88 $\mathrm{ng} \mathrm{g}^{-1}$, 1sd 51, 33 d.f.), but not with crop. 
Table 4. Biomass $\left(\mathrm{ng} \mathrm{g}^{-1}\right.$ ) of amoebae, ciliates and total protozoa at Varois under Bt maize (MEB307Bt) and near-isogenic non-Bt maize (Monumental)

\begin{tabular}{|c|c|c|c|c|c|c|}
\hline Crop & Protozoa & Oct 2002 & May 2003 & Oct 2003 & $1 s d^{\mathrm{a}}$ & d. $f^{a}$ \\
\hline \multirow[t]{3}{*}{ MEB307Bt } & Amoebae & 467 & 878 & 2 & 1024 & 39 \\
\hline & Ciliates & 117 & 29 & 30 & 97 & \\
\hline & Total & 888 & 984 & 100 & 1078 & \\
\hline \multirow[t]{3}{*}{ Monumental } & Amoebae & 1851 & 1475 & 6 & & \\
\hline & Ciliates & 297 & 60 & 75 & & \\
\hline & Total & 2401 & 1652 & 165 & & \\
\hline
\end{tabular}

${ }^{\mathrm{a}}$ see Table 1.

Table 5. Nematodes (no. $\mathrm{g}^{-1}$ ) from Narbons under Bt maize (MEB552Bt), near-isogenic non-Bt maize (DK532), conventional maize (DK312) and recently established (new) or long-term (old) grass

\begin{tabular}{llllllll}
\hline & MEB552Bt & DK532 & DK312 & New grass & Old grass & 1sd $^{\mathrm{a}}$ & d.f $^{\mathrm{a}}$ \\
\hline May 2003 & 17.7 & 16.3 & 16.4 & 15.9 & 32.5 & 10.5 & 80 \\
Oct 2003 & 19.1 & 25.6 & 28.1 & 10.0 & 52.8 & & \\
\hline
\end{tabular}

${ }^{\mathrm{a}}$ see Table 1.

Table 6. Soil water content (\%) and nematodes $\left(\right.$ no. $\left.\mathrm{g}^{-1}\right)$ from Bt and non-Bt maize across all three sites in 2003

\begin{tabular}{llllll}
\hline & & May 2003 & Oct 2003 & lsd $^{\text {a }}$ & d.f $^{\mathrm{a}}$ \\
\hline $\mathrm{Bt}$ & $\mathrm{H}_{2} \mathrm{O}$ & 18.4 & 23.0 & 0.7 & 81 \\
& Nematodes & 18.5 & 19.5 & 4.9 & \\
\multirow{2}{*}{ Non-Bt } & $\mathrm{H}_{2} \mathrm{O}$ & 18.4 & 24.2 & & \\
& Nematodes & 16.5 & 25.9 & & \\
\hline
\end{tabular}

${ }^{\mathrm{a}}$ see Table 1.

\section{Microbial community structure}

Assessments of soil microbial community structure were made using CLPP and PLFA on samples taken in 2003.

At Foulum, in May and October, principal component analysis of the CLPP data and ANOVA of the average well colour development (awcd) clearly separated the microbial community under grass from that under maize $(P<0.001)$. The only differences between maize cultivars were observed in May, when the CLPP calculated from the raw data showed a difference $(P<0.05)$ between DK242 and MEB307Bt. However, when the CLPP was adjusted for awcd, no significant differences between maize cultivars were seen. The awcd for grass was significantly greater $(P<0.001)$ than that for maize in May, but significantly smaller $(P<0.001)$ than under maize in October. There were no significant differences in the amount of microbial biomass, estimated as the total amount of phosphorous contained in the PLFA, between the treatments at the same sampling occasion but the mean microbial biomass in May $\left(26.6 \mathrm{nmol} \mathrm{P} \mathrm{g}^{-1}\right.$, 1sd 5.19 , 9 d.f) was less than in October (48.2, lsd 10.19, 9 d.f). Principal component analysis of the PLFA profiles did not distinguish between the treatments in May, but in October the grass plots had a significantly different profile from all three maize cultivars, as indicated by the second principal component (PC2, 21.9\% of variation accounted for $)(P<0.01)$. There were no differences between the maize cultivars.

At Varois, CLPP from May were indistinguishable between the treatments, but in October, soil from under grass gave a different profile $(P<0.001)$ than that from both $\mathrm{Bt}$ and non-Bt 


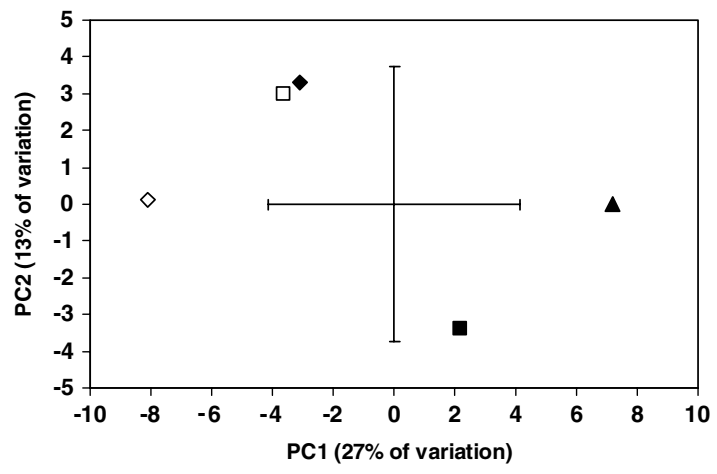

Figure 1. Principal component (PC) plot of the CLPP data from Narbons in October 2003 ( $\bullet$ Bt maize, MEB552Bt; near-isogenic maize, non-Bt, DK432; $\boldsymbol{\Lambda}$, conventional maize, non-Bt, DK312; $\square$, old grass; $\diamond$, new grass). Bars represent the least significant difference $(P<0.05,15$ d.f $)$.

maize. There were no differences between the maize cultivars. The awcd for grass was significantly greater $(P<0.001)$ than that for maize in May, but significantly smaller $(P<0.001)$ than under maize in October. Similarly for PLFA, in May there were no differences in either total biomass (overall mean $28.9 \mathrm{nmol} \mathrm{P} \mathrm{g}^{-1}$, lsd 4.18, 9 d.f ) or profiles between the treatments. In October, however, the grass plots had both a greater biomass $\left(96.2 \mathrm{nmol} P^{-1}\right.$ ) than either of the maize plots (mean of both cultivars $=51.9$, 1sd 21.29, 6 d.f) and significantly different PLFA profiles indicated by $\mathrm{PCl}(51.1 \%$ of variation accounted for, $P<0.05$ ).

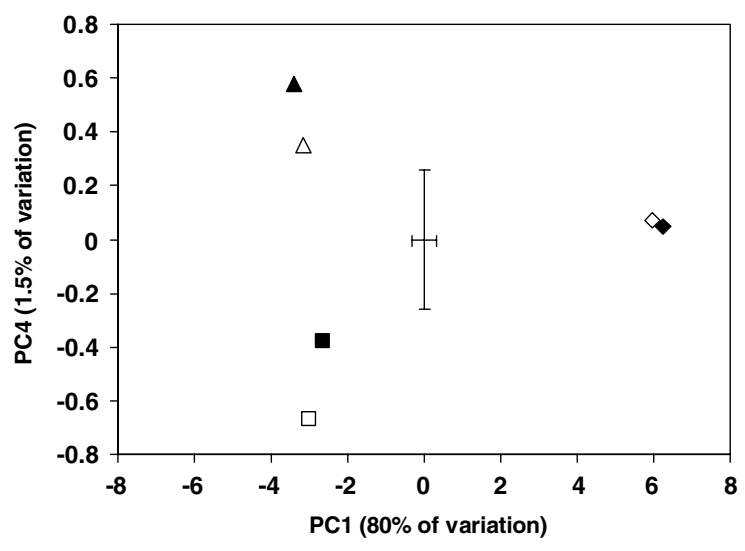

Figure 2. Principal component (PC) plot of the PLFA data from a comparison of three sites $(\bullet$, Foulum, $\boldsymbol{\Delta}$, Narbons, $\mathbf{\square}$, Varois) with Bt maize (open symbols) or non-Bt maize (closed symbols) in October 2003. Bars represent the least significant difference $(P<0.05,15$ d.f $)$.
At Narbons, CLPP from May were indistinguishable between the treatments, but differences were observed in October. Analysis of the raw CLPP data differentiated Bt from both non-Bt cultivars and also the new grass, old grass and maize plots, with $\mathrm{PC} 1 \quad(P<0.05)$ and $\mathrm{PC} 2$ $(P<0.001)$. When the data were adjusted for awcd, however, there were only significant differences with PC1 $(P<0.05)$, which revealed that the microbial community structure under $\mathrm{Bt}$ maize differed from DK312 but not from the near-isogenic DK532, and that the communities under newly sown grass were more divergent than the non-Bt maize cultivars (Figure 1). The awcd for grass was significantly greater $(P<0.001)$ than that for maize in May, but significantly smaller $(P<0.001)$ than under maize in October. Microbial biomass had increased from a mean of $28.1 \mathrm{nmol} \mathrm{P} \mathrm{g}{ }^{-1}$ (lsd 11.36, 15 d.f) in May, with no differences between treatments, to means in October of 113.1 in the old grass plots, which was greater than the mean of the maize and new grass plots (48.4, 1sd 15.21, 15 d.f, $P<0.001)$. The PLFA profiles also differentiated between the old grass and the other treatments in October, as indicated by PC1 $(56.7 \%$ of variation accounted for, $P<0.01)$. There were no differences between the PLFA profiles in May.

In a three site comparison of $\mathrm{Bt}$ and non- $\mathrm{Bt}$, CLPP distinguished between sites in both May and October, using either the raw dataset or data adjusted for awcd, but there were no differences between $\mathrm{Bt}$ or non-Bt maize. In October, when adjusted for awcd, PC1 $(P<0.01,50.3 \%$ of variation) separated Varois from the other sites, while PC2 $(P<0.001,9.4 \%$ of variation $)$ separated Foulum from Narbons. Microbial biomass was not different between the sites in May (overall mean $27.9 \mathrm{nmol} \mathrm{P} \mathrm{g}^{-1}$, 1sd 4.27, 38 d.f), or in October (overall mean $49.0 \mathrm{nmol} \mathrm{P} \mathrm{g}^{-1}$, 1sd 22.15, 38 d.f). Principal component analysis of the PLFA clearly separated the three sites in both May and October, but revealed no differences between $\mathrm{Bt}$ and non-Bt maize. The October data are shown in Figure 2.

Bt maize CrylAB protein quantification at Foulum

In 2002, the Bt expressing MEB307Bt contained an average of $9.99 \mu \mathrm{g}$ Cry $1 \mathrm{Ab}$ protein $\mathrm{g}^{-1}$ plant 


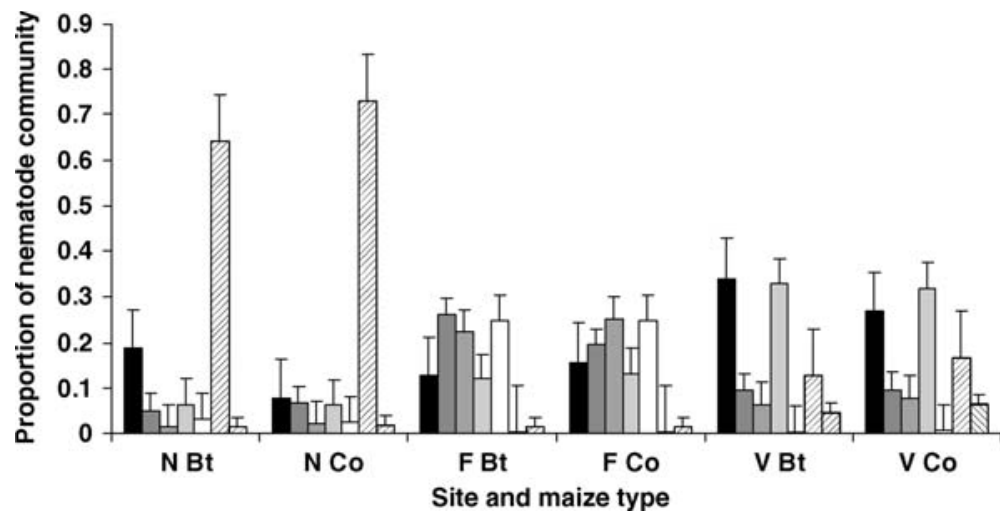

Figure 3. Nematode community structure under Bt maize (Bt) and non-Bt maize (Co) at Narbons (N), Foulum (F) and Varois (V) at harvest in 2003. The nematode communities consisted of fungal-feeding Aphelenchidae ( $\square$ ) and Tylenchidae ( $\square$ ), bacterial-feeding Rhabditidae $(\square)$ and Cephalobidae $(\square)$, plant-feeding Pratylenchus $(\square)$ and Helicotylenchus $(\mathbb{Z})$, and omnivorous Dorylaimidae (\$). Bars represent the lsd $(P<0.05,39$ d.f. $)$.

material (lsd 1.99, 6 d.f, $P<0.001$ ), while Bt protein concentrations in the near-isogenic cultivar Monumental and two samples of the conventional cultivar DK242 were below the detection limit $\left(<0.001 \mu \mathrm{g} \mathrm{g}^{-1}\right)$. A maximum of $0.01 \mu \mathrm{g}$ protein $\mathrm{g}^{-1}$ was detected in two samples of DK242. Concentrations in 2003 were almost identical, being 10.63 and $0.03 \mu \mathrm{g} \mathrm{g}^{-1}$ (lsd 1.07, 6 d.f, $P<0.001)$ for MEB307Bt and A, respectively.

\section{Discussion}

The field sites covered three distinct climatic zones, two broadly different soil types, and two cropping years with the exception of Narbons. The outcome was a sufficiently comprehensive set of data to enable us to explore the consequences of growing GM, Bt-expressing maize on soil microbial and microfaunal (i.e. nematodes and protozoa) populations. One of the strengths of this data set is that it not only allows for a comparison of $\mathrm{Bt}$ versus non-Bt effects, but also between another maize cultivar, a different crop (grass) and of natural variation due to site and year. The benefits of this approach were recognized as recommendations in a report on the effects of GM plants on soil ecosystems (Bruinsma et al., 2002).

There were individual cases of reduced populations of protozoa under the $\mathrm{Bt}$ maize compared to the non-Bt maize (amoebae, ciliates and total protozoa at Varois in October 2002; total protozoa at Varois in October 2003; ciliates and total protozoa at Narbons in October 2003), but no instances of increased populations under the $\mathrm{Bt}$ maize. Those reductions, however, were transient in that they did not persist between sampling occasions. The analysis of populations under $\mathrm{Bt}$ and non-Bt maize at all three sites did detect significantly reduced numbers of nematodes under $\mathrm{Bt}$ maize. The reason for this reduction is probably due to a combination of factors.

Höss et al. (2004) observed a negative correlation between the reproduction of the bacterialfeeding nematode Caenorhabditis elegans and the concentration of CryIAb Bt toxin in a soil bioassay. The results could not distinguish between direct toxic effects on the nematode or indirect effects resulting from changes in bacterial growth, bacterial community structure or other soil properties. There have been reported deleterious effects of toxins from Bacillus thuringiensis ssp. israelensis and ssp. kurstaki on eggs and nematode juveniles (Bottjer et al., 1985; Meadows and Bone, 1990). Our observation that nematode numbers were reduced across all three sites, and that the nematode communities were distinctly different in each site suggests that the effect is generic and not limited to particular nematode groups. As the dominant nematodes at the sites fell into different trophic groups, bacterial-, fungal- and plant-feeders this would suggest that the effect of the $\mathrm{Bt}$ maize is of a direct nature rather than an indirect effect on a specific 
food resource. Whether this is because of the $\mathrm{Bt}$ toxin in the soil itself or some other factor cannot be determined from the data. Manachini et al. (2004) compared nematode communities under Bt (CryIAc) and non-Bt oilseed rape, finding that while population sizes were not significantly different fungal-feeding nematodes were significantly enhanced and plant-feeders significantly reduced under the Bt crop. These authors (Manachini et al., 2004) also concluded that several factors could have been responsible for the observed differences. Measurements from a field site after four years continuous Bt-maize revealed trace amounts of $\mathrm{Bt}$ toxin $\left(<0.1 \mathrm{ng} \mathrm{g}^{-1}\right)$ in whole soil samples but higher concentrations (upto $4.4 \mathrm{ng} \mathrm{g}^{-1}$ ) associated with decomposing maize residues (CryIA; Hopkins and Gregorich, 2003). Our determinations of soil biological parameters over two years in the same plots would also suggest no cumulative effects of the Bt maize, at least in the short term. Spatial distribution of maize residues may be a contributory factor affecting non-target soil organisms. We also observed that the soil under the $\mathrm{Bt}$ maize was drier than that under non-Bt maize, a factor that might also have affected nematode numbers.

Protozoa were unaffected by Bt maize in the comparison of all three sites despite having lower populations in some cases, as described above. This may have been because of the larger variation in protozoan numbers or more dynamic changes in population sizes, as the reproductive rates of protozoa are faster than those of nematodes. Saxena and Stotzky (2001) observed no effect of CryIAb Bt maize on protozoa or nematodes in a pot experiment and concluded that there was no toxic effect of the $\mathrm{Bt}$ protein on these organisms.

Microbial biomass, as indicated by the total amount of phosphorous contained in the phospholipid fatty acid fraction (PLFA-P), was not affected by the Bt maize but generally increased during the cropping season and to a greater extent under grass. Hill et al. (1993) calculated a conversion factor of $419 \mathrm{nmol} \mathrm{P} \mathrm{mg}^{-1}$ biomass $\mathrm{C}$, which gives microbial biomass values in the order of $100 \mu \mathrm{g} \mathrm{C} \mathrm{g}^{-1}$ for the maize plots, similar to that under maize in other studies (Drury et al., 1991). There was also a larger microbial biomass observed under grass than arable soil cropped to wheat (Zelles et al., 1994) and principal component analysis of the PLFA profiles separated the two cropping systems as in this study. Grassland systems tend to be dominated by fungi, rather than bacteria, as indicated by the biomarker PLFA 18:2w6 (Donnison et al., 2000). This particular PLFA was only implicated in the separation of the grass plots at Narbons, where the grass was well-established permanent pasture. At Foulum, the grass had been sown at the same time as the maize, which may not have given enough time for the development of a fungal based microbial community, while at Varois the grass plots were actually dominated by annual weeds.

The assays of microbial community structure indicated that PLFA was more conservative and tended to show fewer differences between treatments than CLPP. This has been remarked on before (Bruinsma et al., 2002; Griffiths et al., 1999) and may indicate that changes revealed by PLFA are of a more fundamental, structural level than indicated by CLPP which incorporates an element of functionality. Widmer et al. (2001) also used both PLFA and CLPP to compare between soils, finding that the relative similarities of the soils varied according to the method and concluding that biological soil comparison was improved if more than one method was used. It was surprising that the PLFA did not distinguish between the three sites in May, while it did in October, as the microbial community is strongly influenced by soil type and even between fields of the same soil type (Wheatley et al., 2003). In a study of PLFA and CLPP profiles from different crops and soils over three years, Schutter et al. (2001) found that season (i.e. May and October) was the most influencial determinant of microbial community structure and that within a season soil type and field properties were more important than farm management. Differences in the microbial profiles, both PLFA and CLPP, cannot be interpreted as better or worse in the same way that reduced numbers or biomass can. Any changes in profile are likely to result from altered root exudation and chemical composition (Grayston et al., 1998), which implies that there were no effective differences between $\mathrm{Bt}$ and nonBt maize in this study.

In a growth chamber experiment comparing maize lines in three different soils, Blackwood and Buyer (2004) detected no change in microbial 
community structure resulting from the expression of CryIAb or CryIF toxin with PLFA but slight $(P<0.05)$ changes in one, clay-rich, soil using CLPP. It was argued that the effect may have been due to the high clay content increasing retention of the Cry protein and so increasing exposure of the rhizosphere microorganisms (Blackwood and Buyer, 2004). We observed some differences in CLPP at Narbons between $\mathrm{Bt}$ and non-Bt varieties but not at Varois which had the highest clay content. To determine which components of the microbial community accounted for the difference would require a more detailed study. Siciliano et al. (1998) examined the rhizosphere microbial community structure of three conventional cultivars of wheat and two conventional and one GM (herbicide tolerant) cultivar of oilseed rape using both CLPP and PLFA. They could detect no differences between the wheat cultivars, while the conventional rape cultivars gave similar profiles that were significantly different from the herbicide tolerant cultivar.

The question then arises whether these observed changes due to the Bt trait are ecologically important. In the context of the current land use, and the time-scale of the study, then we would argue that they are not. Yield of the $\mathrm{Bt}$ and non-Bt maize was equivalent and, as they had both received the same management regime, the effects of the Bt maize on the soil microbial and microfaunal populations had clearly not affected crop growth. Longer term changes such as the accumulation or depletion of soil carbon, the establishment of a diverse flora should the land be taken out of agricultural production, or the growth of a different crop are beyond the scope of this study. We have demonstrated that our methodology was precise enough to detect differences between treatments and that the differences caused by growing GM maize expressing $\mathrm{Bt}$ toxin were not as large as those resulting from growing contrasting but conventional maize cultivars, from growing a different crop plant (in this case grass), or as large as natural differences between sites or sampling occasions. We would argue that the Bt effects, therefore, fall within the normal variation expected in these agricultural systems.

\section{Acknowledgements}

ECOGEN is funded by contract QLK5-CT-200201666 from the European Commission. SCRI receives grant-in-aid from the Scottish Executive Environment and Rural Affairs Department.

\section{References}

Angle J S 1994 Release of transgenic plants: biodiversity and population-level considerations. Mol. Ecol. 3, 45-50.

Blackwood C B and Buyer J S 2004 Soil microbial communities associated with $\mathrm{Bt}$ and non-Bt corn in three soils. J. Environ. Qual. 33, 832-836.

Bottjer K P, Bone L W and Gill S S 1985 Nematoda: susceptibility of the eggs to Bacillus thuringiensis toxins. Exp. Parasitol. 60, 239-244.

Bruinsma M, Kowalchuk G A and van Veen J A 2002 Effects of Genetically Modified Plants on Soil Ecosystems. Netherlands Institute of Ecology, Heteren, Netherlands. 63 pp.

Bruinsma M, Kowalchuk G A and van Veen J A 2003 Effects of genetically modified plants on microbial communities and processes in soil. Biol. Fertil. Soils 37, 329-337.

Darbyshire J F, Wheatley R E, Greaves M P and Inkson R H E 1974 A rapid method for estimating bacterial and protozoan populations in soil. Rev. Ecol. Biol. Sol 11, 465-474.

Donegan K K , Palm C J, Fieland V J, Porteous L A, Ganio L M, Schaller D L, Bucao L Q and Seidler R J 1995 Changes in levels, species and DNA fingerprints of soil microorganisms associated with cotton expressing the Bacillus thuringiensis var. kurstaki endotoxin. Appl. Soil Ecol. 2, 111-124.

Donegan K K, Schaller D L, Stone J K, Ganio L M, Reed G, Hamm P B and Seidler P J 1996 Microbial populations, fungal species diversity and plant pathogen levels in field plots of potato plants expressing the Bacillus thuringiensis var. tenebrionis endotoxin. Transgenic Res. 5, 2535

Donnison L M, Griffith G S, Hedger J, Hobbs P J and Bardgett R D 2000 Management influences on soil microbial communities and their function in botanically diverse haymeadows of northern England and Wales. Soil Biol. Biochem. 32, 253-263.

Drury C F, Stone J A and Findlay W I 1991 Microbial biomass and soil structure associated with corn, grasses and legumes. Soil Sci. Soc. Am. J. 55, 805-811.

Escher N, Kach B and Nentwig W 2000 Decomposition of transgenic Bacillus thuringiensis maize by microorganisms and woodlice. Basic Appl. Ecol. 1, 161-169.

Frostegård A, Tunlid A and Bååth E 1991 Microbial biomass measured as total lipid phosphate in soils of different organic content. J. Microbiol. Methods 14, 151-163.

Grayston S J, Wang S, Campbell C D and Edwards A C 1998 Selective influence of plant species on microbial diversity in the rhizosphere. Soil Biol. Biochem. 30, 369-378.

Griffiths B S, Bonkowski M, Dobson G and Caul S 1999 Changes in the soil microbial community structure in the presence of microbial-feeding nematodes and protozoa. Pedobiologia 43, 297-304. 
Griffiths B S and Caul S 1993 Migration of bacterial-feeding nematodes, but not protozoa, to decomposing grass residues. Biol. Fertil. Soils 15, 201-207.

Groot A T and Dicke M 2002 Insect-resistant transgenic plants in a multi-trophic context. Plant J. 31, 387-406.

Hackett C A and Griffiths B S 1997 Statistical analysis of the time-course of Biolog substrate utilization. J. Microbiol. Methods 30, 63-69.

Hill T C J, McPherson E F, Harris J A and Birch P 1993 Microbial biomass estimated by phospholipids phosphate in soils with diverse microbial communities. Soil Biol. Biochem. 25, 1779-1786.

Hopkins D W and Gregorich E G 2003 Detection and decay of the $B t$ endotoxin in soil from a field trial with genetically modified maize. Eur. J. Soil Sci. 54, 793800

Höss S, Arndt M, Baumgarte S and Tebbe C C 2004 Effects of soil from experimental fields with transgenic corn on the nematode Caenorhabditis elegans. Abstract from Society of Environmental Toxicology and Chemistry, 14th Annual Meeting, Prague, April 2004.

Hurley M A and Roscoe M E 1983 Automated statistical analysis of microbial enumeration by dilution series. J. Appl. Bacteriol. 55, 159-164.

James C 2003 Preview: global status of commercialized transgenic crops: 2003. ISAAA Briefs No.30. International Service for the Acquisition of Agri-biotech Applications, Ithaca, New York.

Jepson P C, Croft B A and Pratt G E 1994 Test systems to determine the ecological risks posed by toxin release from Bacillus thuringiensis genes in crop plants. Mol. Ecol. 3, 81-89.

Manachini B, Fiore M C, Landi S and Arpaia S 2003 Nematode species assemblage in Bt-expressing transgenic eggplant and their isogenic control. In Biodiversity Implications of Genetically Modified Plants. Monte Verità, Ascona, Switzerland, Sept. 7-12, 2003. pp. 31-32.

Manachini B, Landi S, Fiore M C, Festa, M and Arpaia S 2004 First investigations on the effects of Bt-transgenic Brassica napus L. on the trophic structure of the nematofauna. IOBC wprs Bulletin 27, 103-108.

Meadows J and Bone L W 1990 Bacillus thuringiensis strains affect population growth of the free-living nematode Turbatrix aceti. Invert. Reprod. Dev. 17, 73-76.

Nielsen P and Petersen S O 2000 Ester-linked polar lipid fatty acid profiles of soil microbial communities: a comparison of extraction methods and evaluation of interference from humic acids. Soil Biol. Biochem 32, 1241-1249.

Page F C 1976 Taxonomic criteria for Limax amoebae with descriptions of three new species of Hartmanella and three of Vahlkampfia. J. Protozool. 14, 499-521.

Payne R W, Lane P W, Digby P G N, Harding S A, Leech P K, Morgan G W, Todd A D, Thompson R, Tunnicliffe Wilson G, Welhom S J and White R P 1993 Genstat 5 Release Reference Manual. Oxford University Press, Oxford, UK.

Saxena D, Flores S and Stotsky G 2002 Bt toxin is released in root exudates from 12 transgenic corn hybrids representing three transformation events. Soil Biol. Biochem. 34, 133-137.
Saxena D and Stotsky G 2001 Bacillus thuringiensis (Bt) toxin released from root exudates and biomass of Bt corn has no apparent effect on earthworms, nematodes, protozoa, bacteria, and fungi in soil. Soil Biol. Biochem. 33, 1225-1230.

Schmalenberger A and Tebbe C C 2003 Genetic profiling of noncultivated bacteria from the rhizospheres of sugar beet (Beta vulgaris) reveal field and annual variability but no effect of a transgenic herbicide resistance. Can. J. Microbiol. 49, 1-8.

Schutter M E, Sandeno J M and Dick R P 2001 Seasonal, soil type and alternative management influences on microbial communities of vegetable cropping systems. Biol. Fertil. Soils 34, 397-410.

Siciliano S D, Theoret C M, de Freitas J R, Hucl P J and Germida J J 1998 Differences in the microbial communities associated with the roots of different cultivars of canola and wheat. Can. J. Microbiol. 44, 844-851.

Sims S R and Martin J W 1997 Effect of the Bacillus thuringiensis insecticidal proteins CryIA(b), CryIA(c), CryIIA and CryIIIA on Folsomia candida and Xenylla grisea (Insecta: Collembola). Pedobiologia 41, 412-416.

Sims S R and Ream J E 1997 Soil inactivation of the Bacillus thuringiensis subsp. kurstaki CryIIA insecticidal protein within transgenic cotton tissue: laboratory, microcosm and field studies. J. Agr. Food Chem. 45, 1502-1505.

Trevors J T, Kuikman P and Watson B 1994 Transgenic plants and biogeochemical cycles. Mol. Ecol. 3, 57-64.

Wheatley R E, Caul S, Crabb D, Daniell T J, Griffiths B S and Ritz K 2003 Microbial population dynamics related to temporal variations in nitrification in three arable fields. Eur. J. Soil Sci. 54, 707-714.

Wei-Xiang W, Qing-Fe Y and Hang M 2004 Effect of straws from Bt-transgenic rice on selected biological activities in water-flooded soil. Eur. J. Soil Biol. 40, 15-22.

Widmer F, Fließbach A, Laczkó E, Schulze-Aurich J and Zeyer J 2001 Assessing soil biological characteristics: a comparison of bulk soil community DNA-, PLFA-, and Biolog ${ }^{\mathrm{TM}}$-analyses. Soil Biol. Biochem. 33, 1029-1036.

Wilkinson J E, Twell D and Lindsey K 1997 Activities of CaMV 35S and nos promoters in pollen: implications for field release of transgenic plants. J. Exp. Bot. 48, 265-275.

Wolfenbarger L L and Phifer P R 2000 The ecological risks and benefits of genetically engineered plants. Science 290, 2088-2093.

Wu W-X, Ye Q-F, Min H, Duan X-J and Jin W-M 2004 Bttransgenic rice straw affects the culturable microbiota and dehydrogenase and phosphatase activities in a flooded paddy soil. Soil Biol. Biochem. 36, 289-295.

Yu L, Berry R E and Croft B A 1997 Effects of Bacillus thuringiensis toxin in transgenic cotton and potato on Folsomia candida (Collembola: Isotomidae) and Oppia nites (Acari: Oribatidae). J. Econ. Entomol. 90, 113-118.

Zelles L, Bai Q Y, Ma R X, Rackwitz R, Winter K and Beese F 1994 Microbial biomass, metabolic activity and nutritional status determined from fatty acid patterns and poly-hydroxybutyrate in agriculturally managed soils. Soil Biol. Biochem. 26, 439-446. 